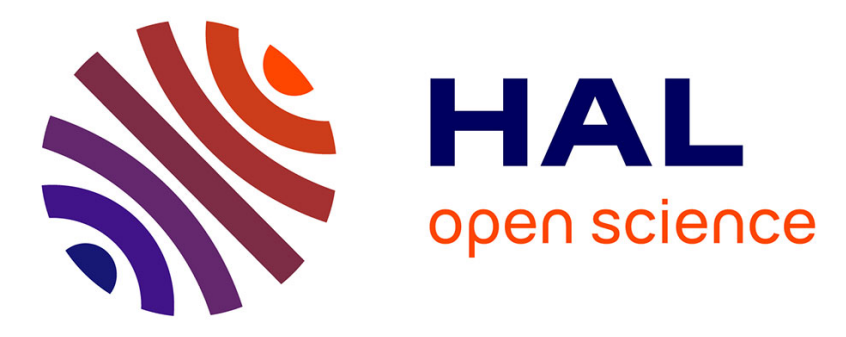

\title{
Gender equity in medical publications: nurses have smashed the glass ceiling
}

Anne-Laure Feral-Pierssens, Aurélie Avondo, de Stefano Carla de Stefano, Sandrine Deltour, Frédéric Lapostolle

\section{To cite this version:}

Anne-Laure Feral-Pierssens, Aurélie Avondo, de Stefano Carla de Stefano, Sandrine Deltour, Frédéric Lapostolle. Gender equity in medical publications: nurses have smashed the glass ceiling. European Journal of Cardiovascular Nursing, 2021, pp.zvab025. 10.1093/eurjcn/zvab025 . hal-03386039

\section{HAL Id: hal-03386039 \\ https://hal.sorbonne-universite.fr/hal-03386039}

Submitted on 19 Oct 2021

HAL is a multi-disciplinary open access archive for the deposit and dissemination of scientific research documents, whether they are published or not. The documents may come from teaching and research institutions in France or abroad, or from public or private research centers.
L'archive ouverte pluridisciplinaire HAL, est destinée au dépôt et à la diffusion de documents scientifiques de niveau recherche, publiés ou non, émanant des établissements d'enseignement et de recherche français ou étrangers, des laboratoires publics ou privés. 
Feral-Pierssens Anne-Laure ${ }^{1}$, Avondo Aurélie², De Stefano Carla3 ${ }^{3}$ Deltour Sandrine ${ }^{4}$, Frédéric Lapostolle $^{2}$

\begin{tabular}{|c|c|}
\hline $\begin{array}{l}1 \text { Feral-Pierssens Anne- } \\
\text { Laure }\end{array}$ & $\begin{array}{l}\text { Centre de recherche sur les innovations en santé (CR-CSIS) } \\
\text { Université de Sherbrooke } \\
\text { Longueuil, Québec, Canada }\end{array}$ \\
\hline${ }^{2}$ Avondo Aurélie & $\begin{array}{l}\text { Service des urgences } \\
\text { Hôpital de la Pitié-Salpétrière } \\
47-83, \text { boulevard de l'hôpital, } 75013 \text {, Paris, France }\end{array}$ \\
\hline $\begin{array}{l}{ }^{3} \text { De Stefano Carla, } \\
\text { Lapostolle Frédéric }\end{array}$ & $\begin{array}{l}\text { SAMU } 93 \text { - UF Recherche-Enseignement-Qualité } \\
\text { Université Paris 13, Sorbonne Paris Cité, Inserm U942 } \\
\text { Hôpital Avicenne, 125, rue de Stalingrad, } 93009 \text { Bobigny, France } \\
\text { Tél : + } 33148964454 \\
\text { Sec : + } 33148964457 \text { / } 55 \text { / } 56 \\
\text { Fax : + } 33148964493\end{array}$ \\
\hline${ }^{4}$ Deltour Sandrine & $\begin{array}{l}\text { Service de neurologie } \\
\text { Hôpital de la Pitié-Salpétrière } \\
\text { 47-83, boulevard de l'hôpital, 75013, Paris, France }\end{array}$ \\
\hline
\end{tabular}

\section{Correspondance}

Pr Frédéric Lapostolle

SAMU 93 - UF Recherche-Enseignement-Qualité

Université Paris 13, Sorbonne Paris Cité, Inserm U942

Hôpital Avicenne, 125, rue de Stalingrad, 93009 Bobigny, France

Tél : + 33148964454

Sec : $+33148964457 / 55 / 56$

Fax : + 33148964493

Mail : frederic.lapostolle@aphp.fr 


\title{
Gender equity in medical publications: nurses have smashed the glass-ceiling
}

\begin{abstract}
Introduction

Gender equity has become a major concern in many professional fields. The rate of women as authors has to be interpreted according to the rate of women in the related professions. In this perspective, studying nurses' population should be of particular interest since, worldwide, nurses are mostly women. Then, our aim was to study gender disparity in nurses' publications.
\end{abstract}

\section{Methods}

We selected the three main journals dedicated to nurse publications: International Journal of Nursing Studies, Journal of Nursing Scholarship and European Journal of Cardiovascular Nursing.

We included 20 recent consecutive papers from each journal. For each paper, the number of authors, their gender and rank were recorded. Primary endpoint: overall rate of women as authors. Secondary endpoints: rate of women as first, last, second and third authors.

\section{Results}

Sixty papers including 322 authors were analyzed. Overall rate of women authors: $74 \%$. Overall rate of women as first author: $82 \%$. Overall rate of women as last author: $72 \%$. Overall rate of women as second and third authors: respectively $80 \%$ and $70 \%$.

\section{Conclusion}

Almost three quarters of the authors in these main scientific journals of nursing studies were female. This rate is lower than the gender rate in the nursing profession. 


\section{Gender equity in medical publications: nurses have smashed the glass-ceiling}

\section{Introduction}

Gender equity has become a major concern in many professional fields (The Economist, 2018; UNESCO, 2014). Inequalities have been recently highlighted in science and in medicine. Many papers, in medical journals, have been recently dedicated to the exploration of the gap between men and women. Studies focusing on female authorship in medical publications, in reviewing process and editorial boards have been largely used as a tool to assess the place of women in medicine. Majors disparities have been reported. Women were first authors in $58 \%$ of psychiatry papers and in $12 \%$ of anaesthesiology papers (Feral-Pierssens, AL et al., 2020). Despite these disparities, authors unanimously concluded that women were underrepresented. The place of women in medical publications seems to give a reliable outline of their place in the society, particularly in sciences. Recent OECD analysis found 'considerable differences' across countries regarding the rate of women with $\mathrm{PhDs}$ as well as the rate of women as first author in publications (Feral-Pierssens, AL et al., 2020).

However, the rate of women as authors has to be interpreted according to the rate of women in the related professions. In this perspective, studying nurses' population should be of particular interest. Indeed, worldwide, nurses are mostly women.(Gunn et al., 2019) The rate of men is close to zero in China or Iceland. In the best case, it reaches one third of the nurses in Saudi-Arabia and Africa.(Boniol et al., 2019) In Europe and in the United-States the rate is close to $15 \%$. Moreover, the recognition of nursing research as an independent and specific academic field is quite recent. This is why, our aim was to study nurses' publications as a way of investigating gender equity in academic leadership and publications of a predominantly female profession. To the best of our knowledge, such analysis has not been performed before.

\section{Methods}

Based on 2018 impact factor, we selected the three main journals dedicated to nurse publications: Then, the first three journals selected were International Journal of Nursing Studies (IJNS; IF = 3.6), Journal of Nursing Scholarship (JNS; IF = 2.5) and European Journal of Cardiovascular Nursing (EJCN; IF = 2.5). We included 20 consecutive papers from each selected journal published before February 2020. For each paper, the number of authors, their gender and rank were recorded. When studied papers included four or less authors, second and third ranks were attributed after first and last authors were filled. Gender was established through first name analysis. When it was not provided in the paper's reference or for epicene name, the author's gender was searched for among the available information from the affiliation (other 
published papers, institutional website, etc.). When it was not possible to determine the author's gender the paper was excluded.

Our primary endpoint was the overall rate of women as authors. Our secondary endpoints were the rate of women as first, last, second and third authors.

\section{Results}

The last 20 consecutive issues published by the three selected journals included 79 papers. Nineteen of them were excluded because gender could not be ascertained. Sixty papers including 322 authors were analyzed.

The overall rate of women authors was $74 \%$ (Table 1). The overall rate of women as first author was $82 \%$ (Table 1). The overall rate of women as last author was $72 \%$. The overall rate of women as second and third authors were respectively $80 \%$ and $70 \%$ (Table 1). Total results and results for each journal are detailed in the tables.

\section{Discussion}

The rate of female authors reported in this study is the highest rate ever reported when investigating gender equity in medical fields' publications.(Feral-Pierssens, AL et al., 2020; Hafeez et al., 2019; Li et al., 2007; The Lancet Infectious Diseases, 2019) Even though these results could be associated to the fact that the rate of women is especially high in the nursing field, the rate of women as authors remain inferior to the rate of women in the nursing profession. Indeed, the rate of men as nurses exceptionally reaches $25 \%$, mostly in Africa countries according to a recent report issued by the WHO.(Boniol et al., 2019) We found disparities according to the papers and the journals (from $60 \%$ to more than $80 \%$ ). The rate of women was lower in the most specialized journal (cardiology). These results might also be explained by the fact that authors' rank and profession (nurse or physician) were not often specified and could not be ascertained in the studied journals. Since female authors rate is much lower in the medical academic field, physicians' implication in nursing papers could be one of the reasons that led to a lower female authors' rate compared to their rate as professionals. Women are constituting the majority of the authors of nursing scientific publications which is rare in the health field. As European Journal of Cardiovascular Nursing is an interdisciplinary journal, it publish also papers in psychology or physical therapy. Then the rate of female in these disciplines has to be taken into consideration. In Europe, psychology and physical therapy graduates are females in respectively 70 to $75 \%$ of the cases. Yet, fostering the involvement of nurses in academic research should be even more instigated. 
The selection of the three first nursing journals could be considered as a limitation to our study. However, focusing on these three main journals with the highest level of publications was relevant since they are the main aim of academic research in nursing studies. Thus, these journals should be involved and stir the leadership in academic publications ensuring and promoting gender equity or at least increasing women implication in scientific production. Knowing the rate of female nurse involved in academic careers would allow us to assess the depth of the gender equity gap between practice and academic research or between academic research and authorship.

\section{Conclusion}

Almost three quarters of the authors in the three main scientific journals of nursing studies were female. It is the highest rate ever reported in studies investigating gender in scientific production in the medical field. It can be explained by the large rate of women working as nurses all around the world. However, this rate is still lower than the gender rate in the nursing profession. One should not forget that dealing with gender representativity and equity in authorship remains a major challenge in many scientific fields, including health studies.

Word count: 969 


\section{References}

Boniol, M., Mclsaac, M., Xu, L., Wuliji, T., Diallo, K., and Campbell, J. (2019). Gender equity in the health workforce: Analysis of 104 countries. World Health Organ. 8.

Feral-Pierrssen, AL, Avondo, A., Apard, M., Monguillet, J., Gonot, A., De Stefano, C., Beggaz, Y., Aguadisch, E., Akodad, H., Deltour, S., et al. (2020). Gender parity in French scientific publications: the glass ceiling. L'Encéphale.

Gunn, V., Muntaner, C., Ng, E., Villeneuve, M., Gea-Sanchez, M., and Chung, H. (2019). Gender equality policies, nursing professionalization, and the nursing workforce: A cross-sectional, time-series analysis of 22 countries, 2000-2015. Int. J. Nurs. Stud. 99, 103388.

Hafeez, D.M., Waqas, A., Majeed, S., Naveed, S., Afzal, K.I., Aftab, Z., Zeshan, M., and Khosa, F. (2019). Gender distribution in psychiatry journals' editorial boards worldwide. Compr. Psychiatry 94 , 152119.

Li, S.F., Latib, N., Kwong, A., Zinzuwadia, S., and Cowan, E. (2007). Gender trends in emergency medicine publications. Acad. Emerg. Med. Off. J. Soc. Acad. Emerg. Med. 14, 1194-1196.

The Economist (2018). Gender parity in science is an uphill struggle. The Economist.

The Lancet Infectious Diseases, null (2019). Gender parity in infectious diseases. Lancet Infect. Dis. $19,217$.

UNESCO (2014). Improving measurement of Gender Equality in STEM | United Nations Educational, Scientific and Cultural Organization. 


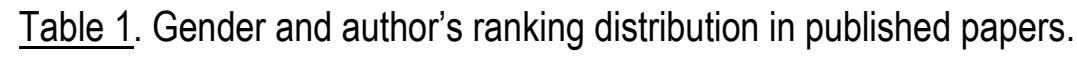

\begin{tabular}{|l|c|c|c|c|c|c|}
\hline $\begin{array}{c}\text { IJNS + JNS } \\
+ \text { EJCN }\end{array}$ & $\begin{array}{c}\text { Total } \\
\text { authors }\end{array}$ & $\begin{array}{c}\text { First } \\
\text { author }\end{array}$ & $\begin{array}{c}\text { Last } \\
\text { author }\end{array}$ & $\begin{array}{c}\text { Second } \\
\text { author }\end{array}$ & $\begin{array}{c}\text { Third } \\
\text { author }\end{array}$ & $\begin{array}{c}\text { Other } \\
\text { rank }\end{array}$ \\
\hline Females & $238(74 \%)$ & $49(82 \%)$ & $41(72 \%)$ & $40(80 \%)$ & $28(70 \%)$ & $80(70 \%)$ \\
\hline Males & $84(26 \%)$ & $11(18 \%)$ & $16(28 \%)$ & $10(20 \%)$ & $12(30 \%)$ & $35(30 \%)$ \\
\hline Total & $322(100 \%)$ & $60(100 \%)$ & $57(100 \%)$ & $50(100 \%)$ & $40(100 \%)$ & $115(100 \%)$ \\
\hline
\end{tabular}

IJNS: International Journal of Nursing Studies; JNS: Journal of Nursing Scholarship; EJCN: European Journal of Cardiovascular Nursing

Table 2. Gender and author's ranking distribution in published papers.

\begin{tabular}{|l|c|c|c|c|c|c|}
\hline IJNS & $\begin{array}{c}\text { Total } \\
\text { authors }\end{array}$ & $\begin{array}{c}\text { First } \\
\text { author }\end{array}$ & $\begin{array}{c}\text { Last } \\
\text { author }\end{array}$ & $\begin{array}{c}\text { Second } \\
\text { author }\end{array}$ & $\begin{array}{c}\text { Third } \\
\text { author }\end{array}$ & $\begin{array}{c}\text { Other } \\
\text { rank }\end{array}$ \\
\hline Females & $89(77 \%)$ & $16(80 \%)$ & $15(79 \%)$ & $15(83 \%)$ & $13(81 \%)$ & $30(71 \%)$ \\
\hline Males & $26(23 \%)$ & $4(20 \%)$ & $4(21 \%)$ & $3(17 \%)$ & $3(19 \%)$ & $12(29 \%)$ \\
\hline Total & $115(100 \%)$ & $20(100 \%)$ & $19(100 \%)$ & $18(100 \%)$ & $16(100 \%)$ & $42(100 \%)$ \\
\hline
\end{tabular}

\begin{tabular}{|l|c|c|c|c|c|c|}
\hline JNS & $\begin{array}{c}\text { Total } \\
\text { authors }\end{array}$ & $\begin{array}{c}\text { First } \\
\text { author }\end{array}$ & $\begin{array}{c}\text { Last } \\
\text { author }\end{array}$ & $\begin{array}{c}\text { Second } \\
\text { author }\end{array}$ & $\begin{array}{c}\text { Third } \\
\text { author }\end{array}$ & $\begin{array}{c}\text { Other } \\
\text { rank }\end{array}$ \\
\hline Females & $82(84 \%)$ & $19(95 \%)$ & $16(80 \%)$ & $12(75 \%)$ & $8(73 \%)$ & $27(87 \%)$ \\
\hline Males & $16(16 \%)$ & $1(5 \%)$ & $4(20 \%)$ & $4(25 \%)$ & $3(27 \%)$ & $4(13 \%)$ \\
\hline Total & $98(100 \%)$ & $20(100 \%)$ & $20(100 \%)$ & $16(100 \%)$ & $11(100 \%)$ & $31(100 \%)$ \\
\hline
\end{tabular}

\begin{tabular}{|l|c|c|c|c|c|c|}
\hline EJCN & $\begin{array}{c}\text { Total } \\
\text { authors }\end{array}$ & $\begin{array}{c}\text { First } \\
\text { author }\end{array}$ & $\begin{array}{c}\text { Last } \\
\text { author }\end{array}$ & $\begin{array}{c}\text { Second } \\
\text { author }\end{array}$ & $\begin{array}{c}\text { Third } \\
\text { author }\end{array}$ & $\begin{array}{c}\text { Other } \\
\text { rank }\end{array}$ \\
\hline Females & $67(61 \%)$ & $14(70 \%)$ & $10(56 \%)$ & $13(81 \%)$ & $7(54 \%)$ & $23(55 \%)$ \\
\hline Males & $42(39 \%)$ & $6(30 \%)$ & $8(44 \%)$ & $3(19 \%)$ & $6(46 \%)$ & $19(45 \%)$ \\
\hline Total & $109(100 \%)$ & $20(100 \%)$ & $18(100 \%)$ & $16(100 \%)$ & $13(100 \%)$ & $42(100 \%)$ \\
\hline
\end{tabular}

IJNS: International Journal of Nursing Studies; JNS: Journal of Nursing Scholarship; EJCN: European Journal of Cardiovascular Nursing 